\title{
Siew New Disease Reports \\ First report of Colletotrichum viniferum causing leaf spot of Hopea odorata in Bangladesh
}

H. Rashid ${ }^{1}$, R. Ahmed ${ }^{1}$, S. Chowdhury ${ }^{1}$, A.K. Azad ${ }^{2}$, T. Raihan ${ }^{2}$ and M.M.U. Haque ${ }^{1 *}$

${ }^{1}$ Department of Forestry and Environmental Sciences, Shahjalal University of Science and Technology, Sylhet 3114, Bangladesh ; ${ }^{2}$ Department of Genetic Engineering and Biotechnology, Shahjalal University of Science and Technology, Sylhet 3114, Bangladesh

*E-mail: masum-fes@sust.edu

Received: 07 Sep 2020. Published: 10 Dec 2020. Keywords: conidia, pathogenicity, sequence

An outbreak of leaf spot disease affecting Hopea odorata was detected during a survey conducted in September 2019 in two different plantations in Sylhet, Bangladesh. The spots on leaves were small, dark brown to blackish and circular to irregular in shape (Fig. 1). They enlarged progressively in size with the maturity of leaves. Diseased leaves were collected, cut into small pieces $(5 \times 5 \mathrm{~mm})$, treated with sodium hypochlorite $(1 \%)$ solution for 30 seconds, and then rinsed with sterile distilled water three times. After drying on filter paper, the pieces were placed aseptically on potato dextrose agar (PDA) amended with kanamycin monosulphate and ampicillin, each at $50 \mu \mathrm{g} / \mathrm{ml}$. The plates were incubated at $25^{\circ} \mathrm{C}$ for four days in the dark to allow fungal growth. The fungal mycelia were sub-cultured several times on the same media amended with the same amount of antibiotics to obtain pure cultures.

Six-day-old colonies on PDA had greyish-white, dense, cottony mycelia (Fig. 2). Mycelial growth was optimal at $25^{\circ} \mathrm{C}$ (radial growth rate, 8.2 $\mathrm{mm} / \mathrm{d}$ ), whereas no growth was observed at $32^{\circ} \mathrm{C}$. Conidia were singlecelled, smooth-walled and cylindrical with rounded ends, the length and width ranged from 14 to $18 \mu \mathrm{m}$ (mean, $15.6 \pm 1.2 \mu \mathrm{m}, \mathrm{n}=50$ ) and 4.5 to 5.5 $\mu \mathrm{m}$ (mean, $4.8 \pm 0.5 \mu \mathrm{m}, \mathrm{n}=50$ ) respectively (Fig. 3). Conidiophores were unbranched and hyaline. Setae were absent but appressoria were observed with various shapes (e.g., ovoid, globose and clavate). All these morphological features suggested that the species was likely to Collectotrichum viniferum as described by Peng et al. (2013). For molecular identification, genomic DNA of one representative isolate was extracted using a genomic DNA extraction kit (Favorgen Biotech Corporation, Taiwan). The complete sequences of the internal transcribed spacer 1 (ITS1) and 5.8S ribosomal DNA (rDNA), and the partial sequences of ITS2 and small subunit of the fungal rDNA were amplified using primers SR6R (forward) and LR1 (reverse) as described by Meyer et al. (2019). A BLAST search with the amplified sequence and a phylogenetic tree revealed that the sequence (GenBank Accession No. MT876535.2) was identical to $C$. viniferum (KX594334) (Fig. 4). The phylogenetic tree was constructed using MEGA7 software (Kumar et al., 2016) as described previously (Azad et al., 2016).

A pathogenicity test was performed using ten detached healthy leaves which were inoculated with $0.5 \mathrm{ml}$ of a $10^{5}$ conidia/ml spore suspension. Sterile distilled water was used as a control. Inoculated leaves were incubated in a growth chamber at $25^{\circ} \mathrm{C}\left( \pm 2^{\circ} \mathrm{C}\right)$ with a 14 -hr photoperiod. Seven days after inoculation, black necrotic spots appeared on the inoculated leaves, whereas the control leaves showed no disease symptoms (Fig. 5). C. viniferum was re-isolated from the necrotic spots of inoculated leaves and re-identified, thus fulfilling Koch's postulates. As per our knowledge, this is the first report on $C$. viniferum causing leaf spot of $H$. odorata in Bangladesh. Further studies and surveys are essential to determine the severity of the disease in different regions of the country, and provide a detailed characterisation of the pathogen.

\section{Acknowledgements}

The authors are thankful to the Research Centre, Shahjalal University of Science and Technology, Bangladesh, for allocating fund to conduct the study (grant no. FES/2018/2/05).

\section{References}

1. Azad AK, Ahmed J, Alum MA, Hasan MM, Ishikawa T, Sawa Y, Katsuhara M, 2016. Genome-wide characterization of major intrinsic proteins in four grass plants and their non-aqua transport selectivity profiles with comparative perspective. PLoS One 11, e0157735. http://dx.doi.org/10.1371/journal.pone.0157735

2. Kumar S, Stecher G, Tamura K, 2016. MEGA7: Molecular evolutionary genetics analysis version 7.0 for bigger datasets. Molecular Biology and Evolution 33, 1870-1874. http://dx.doi.org/10.1093/molbev/msw054

3. Meyer W, Irinyi L, Hoang MTV, Robert V, Garcia-Hermoso D, Desnos-Ollivier M, Yurayart C, Tsang CC, Lee CY, Woo PCY, Pchelin IM, Uhrlaß S, Nenoff P, Chindamporn A, Chen S, Hebert PDN, Sorrell TC, 2019. Database establishment for the secondary fungal DNA barcode translational elongation factor $1 \alpha(T E F 1 \alpha)$. Genome 62, 160-169. http://dx.doi.org/10.1139/gen-2018-0083

4. Peng L-J, Sun T, Yang Y-L, Cai L, Hyde KD, Bahkali AH, Liu ZY, 2013. Colletotrichum species on grape in Guizhou and Yunnan provinces, China. Mycoscience 54, 29-41. http://dx.doi.org/10.1016/j.myc.2012.07.006

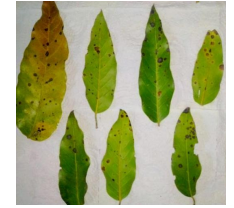

Figure 1

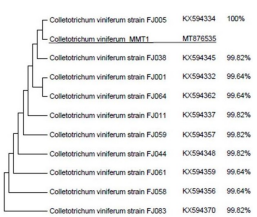

Figure 4

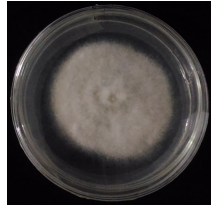

Figure 2

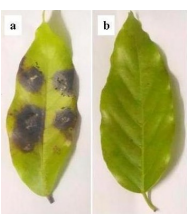

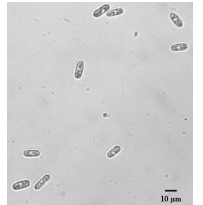

Figure 3

To cite this report: Rashid H, Ahmed R, Chowdhury S, Azad AK, Raihan T, Haque MMU, 2020. First report of Colletotrichum viniferum causing leaf spot of Hopea odorata in Bangladesh. New Disease Reports 42, 19. http://dx.doi.org/10.5197/j.2044-0588.2020.042.019 (c) 2020 The Authors

This report was published on-line at www.ndrs.org.uk where high quality versions of the figures can be found. 